\title{
APPLICATION OF METHODS OF ECONOMIC AND MATHEMATICAL MODELING IN THE SYSTEM OF STAKEHOLDER RELATIONS AND THE FORMATION AND IMPLEMENTATION OF SOCIAL CORPORATE RESPONSIBILITY OF CONSTRUCTION ENTERPRISES
}

\author{
ЗАСТОСУВАННЯ МЕТОДІВ ЕКОНОМІКО-МАТЕМАТИЧНОГО \\ МОДЕЛЮВАННЯ У СИСТЕМІ СТЕЙКХОЛДЕРНИХ ВІДНОСИН \\ ТА ФОРМУВАННІ Й РЕАЛІЗАЦІЇ СОЦІАЛЬНОЇ КОРПОРАТИВНОЇ \\ ВІДПОВІДАЛЬНОСТІ БУДІВЕЛЬНИХ ПІДПРИЄМСТВ
}

UDC 334.021:658:69.009

https://doi.org/10.32843/infrastruct40-24

\section{Velychko Volodymyr}

Candidate of Economic Sciences,

Assistant Lecturer at Department

of Entrepreneurship and Business Administration

O.M. Beketov National University of Urban Economy in Kharkiv

Grytskov Evgen

Candidate of Economic Sciences,

Senior Lecturer at Department of

Entrepreneurship and Business

Administration

O.M. Beketov National University of Urban

Economy in Kharkiv

Zubarev Dmitriy

Postgraduate Student at Department of

Entrepreneurship

and Business Administration

O.M. Beketov National University of Urban

Economy in Kharkiv
The aim of the study is to identify areas and features of the application of methods of economic and mathematical modeling in the system of stakeholder relations and the formation and implementation of social corporate responsibility of construction companies. The proposed areas of economic and mathematical modeling of the influence of the systemic factor of stakeholder relations on the integral indicator of the formation and use of social corporate responsibility of construction companies. It was determined that in order to increase the efficiency of the formation and implementation of social corporate responsibility of construction enterprises, it is necessary to form a quantitative basis that takes into account stakeholders and the level of interaction of stakeholders. Based on the developed quantitative basis, reasonable management decisions are made in the areas of interaction between stakeholders and ensuring the formation and implementation of social corporate responsibility of construction companies.

Key words: stakeholder relations, social corporate responsibility, construction enterprises, stakeholders, system factor, integrated indicator, economic and mathematical modeling, adequacy criteria.

Целью исследования является определение сорер и выявление особенностей применения методов экономико-математического моделирования в системе взаимодействия с заинтересованными сторонами, фрормирования и реализации социальной корпоративной ответственности строительных компаний. Предложены направления экономико-математического моделирования влияния системного фрактора взаимодействия заинтересованных сторон на интегральный показатель формирования и использования социальной корпоратив ной ответственности строительных компаний. Определено, что для повышения эфрфективности формирования и реализации социальной корпоративной ответственности строительных предприятий необходимо сорормировать количественную основу, учитывающую уровень взаимодействия заинтересованных сторон. На основе разработанной количественной базы принимаются обоснованные управленческие решения в сорерах взаимодействия заинтересованных сторон и обеспечения формирования и реализации социальной корпоративной ответственности строительных компаний.

Ключевые слова: стейкхолдерные отношения, социальная корпоративная ответственность, строительные предприятия, стейкхолдеры, системный фрактор, интегральный показатель, экономико-математическое моделирование, критерии адекватности.

Доведена необхідність застосування методів економіко-математичного моделювання у системі стейкхолдерних відносин та фрормуванні й реалізації соціальної корпоративної відповідальності будівельних підприємств. Метою дослідження є визначення напрямів та виявлення особливостей застосування методів економіко-математичного моделювання у системі стейкхолдерних відносин та фрормуванні й реалізації соціальної корпоративної відповідальності будівельних підприємств. Для досягнення поставленої мети вирішуються наступні завдання: визначення напрямів економіко-математичного моделювання впливу стейкхолдерних відносин на рівень сочіальної корпоративної відповідальності будівельних підприємств; характеристика критеріїв адекватності економіко-математичної моделі; представлення результатів економіко-математичного моделювання та їх інтерпретація. Запропоновані напрями здійснення економіко-математичного моделювання впливу системного чинника стейкхолдерних відносин на інтегральний показник фрормування та використання соціальної корпоративної відповідальності будівельних підприємств. Визначено системний чинник визначення видів стейкхолдерів, які взаємодіють у системі формування та реалізації соціальної корпоративної відповідальності будівельних підприємств. Побудовано економіко-математичну модель та визначені ії критерії адекватності. Критерії адекватності, що свідчать про рівень впливу системного стейкхолдерного чинника на інтегральний показник формування й реалізації соціальної корпоративної відповідальності будівельних підприємств, вказують на достовірність та повноту встановлених зв'язків. Визначено, що для зростання ефективності фоормування й реалізації соціальної корпоративної відповідальності будівельних підприємств необхідно сформувати кількісне підгрунтя, які враховують стейкходлерні чинники та рівень взаємодії зацікавлених осіб. На основі розробленої кількісної основи приймаються обірунтовані управлінські рішення щодо напрямів взаємодії стейкхолдерів та забезпечення формування й реалізації соціальної корпоративної відповідальності будівельних підприємств.

Ключові слова: стейкхолдерні відносини, соціальна корпоративна відповідальність, будівельні підприємства, стейкхолдери, системний чинник, інтегральний показник, економіко-математичне моделювання, критерії адекватності.

Problem Statement. Current business conditions require the adoption of sound management decisions to ensure stakeholder relations and the formation of social corporate responsibility of construction companies. The current state of these enterprises is determined by ambiguity, which is associated with a decrease in production and economic potential, a slowdown in the growth of key performance indicators, and the negative influence of external and internal factors. In such conditions, the development and use of an appropriate decision-making basis is of particular importance, and is formed on a quantitative basis. Its creation involves the application of modern methods of economic and mathematical modeling in 
the system of stakeholder relations and the formation and implementation of corporate social responsibility as important factors affecting the development of construction enterprises. Thus, the research topic is relevant, and its development is timely.

Literature Review. The application of methods of economic and mathematical modeling in the study of economic processes are presented in scientific developments [1-9]. Along with this, there are unresolved issues regarding the application of methods of economic and mathematical modeling in the system of stakeholder relations and the formation of social corporate responsibility of construction companies.

Research Objective is to identify areas and identify features of the application of methods of economic and mathematical modeling in the system of stakeholder relations and the formation and implementation of social corporate responsibility of construction companies.

To achieve this goal, the following tasks are solved:

- determination of the directions of economic and mathematical modeling of the influence of stakeholder relations on the level of social corporate responsibility of construction enterprises;

- characterization of the criteria for the adequacy of the economic and mathematical model;

- presentation of the results of economic and mathematical modeling and their interpretation.

Key Results. Economic and mathematical modeling for research is implemented in the following areas:

1. The use of information and analytical support based on the assessment of the integral indicator of the formation and implementation of social corporate responsibility and the system factor of the level of stakeholder relations of construction enterprises.

2. Establishing the relationship between the integral indicator of the formation and implementation of social corporate responsibility and the system factor of the level of stakeholder relations based on the correlation and determination coefficient.

3. Construction of correlation fields, economic and mathematical models of the influence of the system factor on an integral indicator of the level of formation and implementation of social corporate responsibility of construction companies.

4. Definition of criteria that determine the adequacy of the developed economic and mathematical models.

5. Interpretation of the established relationships between the integral indicator of the formation and implementation of social corporate responsibility of construction companies and the systemic factor.

Summarizing the existing legal support for certain types of stakeholders that affect the social corporate responsibility of construction companies and form a systemic stakeholder structural factor $\left(S K V_{1}\right)$ : government bodies; bodies of state architectural and construction control $\left(S K V_{12}\right)$; government bodies providing development and implementation of urban planning documentation $\left(S K V_{13}\right)$; bodies for the formation of the urban cadastre $\left(S K V_{14}\right)$; bodies providing the formation and use of land $\left(S K V_{15}\right)$; subjects of architectural activity $\left(S K V_{16}\right)$; social security authorities $\left(S K V_{17}\right)$; bodies ensuring responsibility of enterprises, their associations, institutions and organizations for violations in the field of urban planning $\left(S K V_{18}\right)$; housing reconstruction bodies $\left(S K V_{19}\right)$; bodies carrying out architectural and technical supervision during the construction of an architectural object $\left(S K V_{110}\right)$; bodies authorized to consider cases of violations in the field of urban development $\left(S K V_{111}\right)$; domestic stakeholders engaged in investment activities in the construction industry $\left(S K V_{112}\right)$; stakeholders providing the implementation of scientific and technical activities in construction $\left(S K V_{113}\right)$, contractor $\left(S K V_{114}\right)$; subjects providing innovative activity $\left(S K V_{115}\right)$; customer $\left(S K V_{116}\right)$; financial and credit institutions $\left(S K V_{117}\right)$; organizations providing interaction with construction companies in the field of securities transactions $\left(S K V_{118}\right)$; organizations that exercise external and internal control over the financial and economic activities of construction enterprises $\left(S K V_{119}\right)$; insurance companies and companies that interact with construction enterprises $\left(S K V_{120}\right)$; stakeholders supporting the formation and implementation of foreign investment $\left(S K V_{121}\right)$; bodies providing external control over the activities of construction enterprises $\left(S K V_{122}\right)$; workers $\left(S K V_{123}\right)$; corporate governance bodies of construction enterprises $\left(S K V_{124}\right)$; founder $\left(S K V_{125}\right)$; top management $\left(S K V_{126}\right)$; managers of different levels $\left(S K V_{127}\right)$; other stakeholders $\left(S K V_{128}\right)$.

The systemic factor that determines the types of stakeholders that interact in the system of formation and implementation of social corporate responsibility $\left(S K V_{1}\right)$ is based on the following model:

$$
\left\{\begin{array}{c}
S K V_{11}, S K V_{12}, S K V_{13}, S K V_{14}, S K V_{15}, S K V_{16} \\
S K V_{17}, S K V_{18}, S K V_{19}, S K V_{110}, S K V_{111}, S K V_{112}, \\
S K V_{113}, S K V_{114}, S K V_{115}, S K V_{116}, S K V_{117}, S K V_{118}, \\
S K V_{119}, \quad S K V_{120}, S K V_{121}, S K V_{122}, \quad S K V_{123}, S K V_{124}, \\
S K V_{125}, S K V_{126}, S K V_{127}, S K V_{128}
\end{array}\right\} \subset S K V_{1},
$$

The proposed economic and mathematical model for assessing the systemic factor in determining the types of stakeholders that interact in the system of formation and implementation of social corporate responsibility of construction enterprises:

$$
S K V_{1}=\sqrt{\begin{array}{c}
S 8 \\
\begin{array}{c}
S K V_{11} x S K V_{12} x S K V_{13} x S K V_{14} x S K V_{15} x S K V_{16} x S K V_{17} x S K V_{18} x S K V_{19} \\
x S K V_{111} x S K V_{112} x S K V_{113} x S K V_{114} x S K V_{115} x S K V_{116} x S K V_{117}
\end{array} \\
x S K V_{118} x S K V_{119} x S K V_{120} x S K V_{121} x S K V_{122} x S K V_{123} x S K V_{124} x S K V_{125} \\
x S K V_{126} x S K V_{127} x S K V_{128}
\end{array}}
$$

The adequacy criteria of the economic and mathematical model determine the influence of stakeholder relations on the level of social corporate responsibility of construction enterprises as follows:

correlation coefficient $(R)$ : determined based on model: 


$$
R=\frac{\sum_{i=1}^{n}\left(X_{i}-\bar{X}\right) x\left(Y_{i}-\bar{Y}\right)}{\sqrt{\sum_{i=1}^{n}\left(X_{i}-\bar{X}\right)^{2}} \times \sum_{i=1}^{n}\left(Y_{i}-\bar{Y}\right)^{2}},
$$

$X_{i}, Y_{i}$ - values of quantities between which connections are established;

$\bar{X}, \bar{Y}$ - average values of integral indicators.

The correlation coefficient determines the level of influence of the independent variable $x$ on the dependent factor $c$. The value of the correlation coefficient varies in the range from -1 to 1 . A positive or negative value determines either direct or feedback between the indicators. Modulo the values of the correlation coefficient - if the indicator is 0 - there is no connection between the indicators;

- from 0.01 to 0.2 - low;

$-0.201-0.4-$ inconsequential;

- 0.401 - 0.6 - moderate;

- $0.601-0.8$ - significant;

- $0.801-0.99$ - high;

-1 - absolute.

The essence of the correlation coefficient is determined by how much the dependent variable changes from the independent one;

coefficient of determination $\left(R^{2}\right)$ : definition model:

$$
R^{2}=\sqrt{ } R \text {. }
$$

The determination coefficient is a more precise criterion that determines the level of influence of an independent variable on a dependent one; its value varies from 0 to 1 - depending on the level of their influence;

Student's t-test: assessment model:

$$
t=\frac{M_{1}-M_{2}}{\sqrt{m_{1}^{2}+m_{2}^{2}}},
$$

$M_{1}, M_{2}$ - arithmetic mean values;

$m_{1}, m_{2}$ - the value of statistical errors of arithmetic mean integral indicators.

Student's t-test determines the feasibility of established relationships. Based on the student criterion, actual values are determined, which are compared with the corresponding standard values that are presented in the developed tables. In cases where the actual values of Student's t-test exceed its normative values, the established relationships are advisable and the study of relationships continues. Otherwise, the connection is unstable and impractical. In this case, the model is considered inadequate;

Fisher's F-test: determination model:

$$
F=\frac{R^{2}}{1-R^{2}} x \frac{(n-m-1)}{m},
$$

$n$ - number of observations regarding integral indicators.

It determines the level of materiality and significance of the established relationships between integral indicators. In this case, the actual value of the Fisher's F-test is determined, which is compared with its normative values, which are presented in the corresponding tables. In the case when the actual value of the Fisher's F-test exceeds its normative value, then the relationships between the integral indicators are taken significant. Otherwise, the economic and mathematical model is inadequate and further studies are not carried out;

- criteria for testing for homo or heteroscedasticity: determined by the Goldfeld-Quandt test, Glaser's models, by the criterion $\mu$. The degree of homogeneity of the residual indicators of the economic and mathematical model is determined. If the distribution of residues is uniform, then homoscedasticity is confirmed (the value of $\mu$ is determined). If the distribution of the residues is not homogeneous, then heteroscedasticity is confirmed by the value of $\mu$. At the same time, the level of adequacy of the economic and mathematical model is characterized: hemoscedastic rests - adequacy model;

- Heteroscedasticity of residues - the model is inadequate;

- Durbin-Watson criterion (DW): it is determined by the model:

$$
D W=\frac{\sum\left(e_{i}-e_{i-1}\right)^{2}}{\sum e_{i}^{2}}
$$

$e_{i}, e_{i-1}-$ residuals of integral indicators.

The actual value of the Durbin-Watson criterion is compared with tabular values. If the value of the DW criterion is less than 2 , then the following options are possible:

- if the actual DW value is lower than the lowest tabular DW value, then the null hypothesis of the absence of autocorrelation is discarded and a conclusion is made about the positive autocorrelation in the residuals;

- if the actual value of DW is greater than the upper tabular value of DW, the null hypothesis of the absence of autocorrelation is not rejected and the conclusion is made that there is no correlation between the following residues and the previous ones;

- if the actual DW value is between the lower and upper values of the Durbin-Watson criterion, neither the hypothesis of the absence of autocorrelation in the residues can be rejected or accepted. This requires further research.

If the actual value of the DW criterion is more than 2 , it is a negative autocorrelation.

Comparison of the limit value of the DurbinWatson criterion with the actual value of $4-\mathrm{DW}$ possible results:

- at 4 - DW, the lower value of the lower boundary of the criterion is lower, the null hypothesis about the absence of autocorrelation is rejected and the conclusion is made about the presence of negative autocorrelation in the residues;

- when 4-DW is greater than the upper boundary of the Durbin-Watson criterion, the null hypothesis is accepted about the absence of autocorrelation in the residues; 
The results of determining the Fisher and Student's criteria by the model of the influence of the systemic stakeholder factor on the integral indicator of the formation and implementation of social corporate responsibility of construction enterprises, rel. units (Developed by the authors)

\begin{tabular}{|c|c|}
\hline $\begin{array}{c}\text { The calculated values of } F \text { and } t \text { criteria of the } \\
\text { Fisher and Student's tests }\end{array}$ & $\begin{array}{c}\text { Standard values F and } \mathbf{t} \text { of the Fisher and Student's } \\
\text { criteria (at a significance level of 0.05) }\end{array}$ \\
\hline$F_{S K V}=43.1$ & $F_{H}=3.44$ \\
$t_{S K V}=27.6$ & 2.31 \\
$t_{S K V}=17.2$ & $t_{H}$
\end{tabular}

- if $4-D W$ is between the values of the lower and lower grades of the Durbin - Watson criterion, then it is impossible to conclude either the presence or absence of autocorrelation of residues.

The proposed test allows to check the economic and mathematical model for autocorrelation. If it is positive, then it is possible to obtain false results of estimates, if autocorrelation is negative, then the model is adequate;

- criteria for checking for multicollinearity: the degree of impact of one independent variable on another independent variable with the corresponding pair correlation coefficient is estimated.

The phenomenon of multicollinearity leads to a bias in the estimates of the results of economic and mathematical modeling, and reduces the effectiveness of the study. The level of multicollinearity is as follows:

- the correlation coefficient between independent variables is equal to:

-0 - lack of multicollinearity;

$-0.01-0.2$ - low multicollinearity;

$-0.201-0.4-$ minor;

$-0.401-0.6$ - moderate;

$-0.601-0.8$ - significant;

$-0.801-0.99$ - high;

-1 - absolute.

In cases when the value of the coefficient of pair correlation between independent variables exceeds 0.601 (the values are confirmed, a high or absolute level of multicollinearity), then a decision is made to exclude one of the independent factors from the economic and mathematical model.

Otherwise (absent, low, negligible or mediocre level of multicollinearity), a decision is made on the remainder of the independent variables in the economic and mathematical model.

Applying the economic and mathematical model (1.2), the systemic factor is determined for identifying the types of stakeholders that interact in the system of formation and implementation of social corporate responsibility of construction enterprises:

$$
S K V_{1}=3,3 .
$$

Based on the generated information and analysis support, a model of the influence of the systemic stakeholder factor on the integral indicator of the formation and implementation of social corporate responsibility of construction enterprises was built:

$$
S K V_{\square}=0,04 \times S K V_{1}-0,01 \text {. }
$$

$S K V$ - an integral indicator of the formation and implementation of social corporate responsibility of construction companies.

The adequacy criteria, indicating the degree of influence of the systemic stakeholder factor on the integral indicator of the formation and implementation of social corporate responsibility of construction enterprises, are as follows:

- correlation coefficient $(R)-0.72$;

- coefficient of determination $\left(R^{2}\right)-0.52$.

The results of determining the Fisher and Student's criteria for models of the influence of the systemic stakeholder factor on the integral indicator of the formation and implementation of social corporate responsibility of construction companies are presented in Table 1.

Testing economic and mathematical models in homo or heteroscedasticity indicates homogeneity of the distribution of bonds, since the calculated value of the criterion $\mu$ does not exceed its normative values: $\mu_{\text {calc }}(1.12)<$ changes in the systemic stakeholder factor by $52 \%$ determine the transformation of the integral indicator of the formation and implementation of social corporate responsibility of construction enterprises;

- a $1 \%$ increase in the systemic stakeholder factor leads to an increase in the integral indicator of the formation and implementation of corporate social responsibility by $4 \%$ and vice versa;

- the values of the correlation and determination coefficients are presented; they indicate a moderate influence of the systemic stakeholder factor on the integral indicator of the formation and implementation of social corporate responsibility of construction enterprises;

- in the formation and implementation of social corporate responsibility, it is necessary to take into account stakeholder factors and the interaction of types of stakeholders;

- in order to increase the effectiveness of the formation and implementation of social corporate responsibility, it is necessary to develop measures to increase the effectiveness of interaction with stakeholders of construction enterprises.

Conclusion. As a result of the study, it was found that in order to increase the efficiency of the formation and implementation of social corporate responsibility of construction enterprises, it is necessary to form a quantitative basis that takes into account stakeholders and the level of interaction of interested parties. 
Based on the developed quantitative basis, reasonable management decisions are made in the areas of interaction between stakeholders and ensuring the formation and implementation of social corporate responsibility of construction companies.

\section{БІБЛІОГРАФІЧНИЙ СПИСОК:}

1. Вітлінський В. В. Моделювання економіки: навч. посібник. К.: КНЕУ, 2003. 408 с.

2. Грицьков $€$. В. Організаційно-економічне забезпечення управління інтелектуальним капіталом на будівельних підприємствах: автореф... канд. екон. наук: 08.00.04. Х.: ХНУМГ імені О. М. Бекетова, 2016. 21 c.

3. Доугерти К. Введение в эконометрику: пер. с англ. М.: ИНФРА-М, 1997. 402 с.

4. Єлейко В. Основи економетрії. Львів: «Марка ЛТД», 1995. 191 с.

5. Колодницький М. М. Основи теорії математичного моделювання систем. Житомир, 2001. 718 с.

6. Лук'яненко І. Г., Краснікова Л. І. Економетрика: підручник. К.: Знання, 1998. 494 с.

7. Пономаренко О. І., Пономаренко В. О. Системні методи в економіці, менеджменті та бізнесі: навч. посібник. К.: Либідь, 1995. 240 с.

8. Пруненко Д. О. Теоретико-методологічні аспекти фрормування та реалізації стратегії управління інтелектуальним капіталом будівельних підприємств: дис. ... д-ра екон. наук: 08.00.04. Харків: ХНУМГ імені О. М. Бекетова, 2019. 604 с.

9. Розен В. В. Математические модели принятия решений в экономике: учебн. пособие. М.: КД «Университет», 2002. 288 с.

\section{REFERENCES:}

1. Vitlinskyy V. V. (2003) Modeliuvannia ekonomiky [Modeling the economy]. Kyiv: KNEU. (in Ukrainian)

2. HrytskovYe.V.(2016)Orhanizatsiino-ekonomichne zabezpechennia upravlinnia intelektualnym kapitalom na budivelnykh pidpryiemstvakh [Organizational and economic support of intellectual capital management at construction enterprises]: (PhD Thesis). Kharkiv.

3. Dougerti K. (1997) Vvedenie v ekonometriku [Introduction to Econometrics]. Moskow: INFRA-M. (in Russian)

4. Ieleyko V. (1995) Osnovy ekonometrii [Econometrics basics]. Lviv: «Marka LTD». (in Ukrainian)

5. Kolodnytskyy M. M. (2001) Osnovy teorii matematychnoho modeliuvannia system [Basics of the theory of mathematical modeling of systems]. Zhytomyr. (in Ukrainian)

6. Lukianenko I. H., Krasnikova L. I. (1998) Ekonometryka [Econometrics]. Kyiv: Znannia. (in Ukrainian)

7. Ponomarenko O. I., Ponomarenko V. O. (1995) Systemni metody $v$ ekonomitsi, menedzhmenti ta biznesi [System methods in economics, management and business]. Kyiv: Lybid. (in Ukrainian)

8. Prunenko D. O. (2019) Teoretyko-metodolohichni aspekty formuvannia ta realizatsii stratehii upravlinnia intelektualnym kapitalom budivelnykh pidpryiemstv [Theoretical and methodological aspects of the formation and implementation of the strategy of management of intellectual capital of construction enterprises]: (PhD Thesis). Kharkiv.

9. Rozen V. V. (2002) Matematicheskie modeli prinyatiya reshenii $v$ ekonomike [Mathematical models of decision making in economics]. Moskow: KD «Universitet». (in Russian) 